\title{
Promoting EFL Learner Autonomy in a Teacher-Centered Culture through Video- Sharing and Collaborating in Online Forums
}

El desarrollo de la autonomía del estudiante de inglés como lengua extranjera en una

cultura enfocada en el profesor, por medio de videos y foros compartidos en línea

Promover a autonomia do estudante de inglês como língua estrangeira em uma cultura centrada no professor compartilhando vídeos e colaborando em fóruns on-line

Roger EDWARDS

Universidad Técnica de Ambato, Ecuador. rs.edwards@uta.edu.ec https://orcid.org/oooo-0002-I398-4446

María Daniela HOLGUÍN-BARRERA

Universidad Técnica de Ambato, Ecuador.

md.holguin@uta.edu.ec

https://orcid.org/oooo-0002-9602-9400

Ana Cristina ORTIZ

Universidad Técnica de Ambato, Ecuador.

ac.ortiz@uta.edu.ec

https://orcid.org/oooo-0002-6059-4942

Mariela PÉREZ

Universidad Técnica de Ambato, Ecuador.

fm.perez@uta.edu.ec

https://orcid.org/0000-0002-1600-267 I

Received: 28/06/2019

Sent to peer review: $11 / 07 / 2019$

Accepted by peers: 02/09/2019

Approved: 10/09/2019

DOI: 10.5294/laclil.2019.12.1.5

To reference this article (APA) / Para citar este artículo (APA) / Para citar este artigo (APA) Edwards, R., Holguín-Barrera, M. D., Ortiz, A. C., \& Pérez, M. (2019). Promoting EFL learner autonomy in a teacher-centred culture through video-sharing and collaborating in online forums. Latin American Journal Of Content \& Language Integrated Learning, 12(1), 99-127. DOI: https://doi.org/10.5294/laclil.2019.12.1.5 
ABSTRACT. This action research was undertaken at a university language center in Ambato, Ecuador, as a result of concerns over the high level of teacher dependence among learners of English as a Second Language (EFL). The project aimed at assessing the development of autonomous learning behavior and the motivational impact of student collaboration on encouraging a change in student behavior toward autonomy. The participating students were 154 EFL students of lower advanced levels who engaged in a 5-week intervention addressed at encouraging autonomous listening comprehension practice through videos. Participants used the Moodle ${ }^{\otimes}$ platform to share videos with peers of the same level, who were also able to post comments on the content of the videos. Quantitative and qualitative parameters were used to assess the achievement of two objectives: the extent of the development of autonomous behavior; and the extent of the motivational impact of student collaboration on encouraging autonomous behavior. Analysis of participation showed development of student autonomy when measured against three of the four parameters used. Analysis of feedback showed the platform-based collaborative learning strategy had a significant impact on student motivation and engagement during the intervention. Feedback included the recommendation to extend and improve the intervention, while complementing it with a medium to allow greater interaction in real time.

Keywords (Source: Unesco Thesaurus): Learner autonomy; learning beyond the classroom; collaborative learning; English as a Foreign Language; EFL; listening.

RESUMEN. La presente investigación tuvo lugar en el centro de idiomas de una universidad pública en Ambato, Ecuador, debido al alto nivel de dependencia hacia el profesor existente en estudiantes de inglés. El proyecto se enfocó en evaluar el desarrollo del aprendizaje autónomo y el impacto motivacional de la colaboración entre estudiantes para promover un cambio de comportamiento del estudiante hacia la autonomía. Participaron 154 estudiantes de inglés de niveles avanzados, quienes colaboraron en una intervención de cinco semanas, cuyo objetivo fue motivar la práctica de la comprensión auditiva a través de videos. Se utilizó la plataforma Moodle® para compartir videos con compañeros del mismo nivel, quienes pudieron comentar sobre el contenido de los mismos. Se utilizaron parámetros cuantitativos y cualitativos para evaluar el cumplimiento de dos objetivos: el alcance del comportamiento autónomo; y el alcance del impacto motivacional de colaboración entre estudiantes para fomentar el comportamiento autónomo. El análisis de participación mostró desarrollo de la autonomía en el estudiante, contrastado con tres de los cuatro parámetros usados. El análisis de la retroalimentación mostró que la colaboración basada en Moodle $®$ tuvo un impacto significativo en la motivación y participación del estudiante durante la intervención. La retroalimentación incluyó la recomendación de expandir y mejorar la intervención, complementándola con un medio que facilite mayor interacción en tiempo real.

Palabras clave (Fuente: tesauro de la Unesco): autonomía del estudiante; aprendizaje fuera del aula de clase; aprendizaje colaborativo; inglés como lengua extranjera; ILE; escuchar.

RESUMO. Esta pesquisa educativa foi realizada no centro de idiomas de uma universidade pública da cidade de Ambato, Equador, como resultado do alto nível de dependência do professor pelo estudante de inglês. O projeto focou-se em avaliar o desenvolvimento da aprendizagem autônoma e o impacto motivacional da colaboração entre os estudantes para promover uma mudança no comportamento dos alunos em relação à autonomia. Os participantes foram 154 estudantes pertencentes aos níveis avançados, que colaboraram em uma intervenção de cinco semanas, cujo objetivo era motivar a prática da compreensão auditiva por meio de vídeos. Foram utilizados parâmetros quantitativos e qualitativos para avaliar o cumprimento de dois objetivos da pesquisa: o escopo do desenvolvimento do comportamento autônomo; e o escopo do impacto motivacional da colaboração dos alunos para promover o comportamento autônomo. A análise de participação e feedback mostrou o desenvolvimento da autonomia do aluno quando comparado com três dos quatro parâmetros utilizados. A análise de feedback mostrou que a colaboração baseada em Moodle® teve um impacto significativo na motivação e participação do aluno durante a intervenção. O feedback incluiu a recomendação de expandir e melhorar a intervenção, complementando-a com um meio que facilite uma maior interação em tempo real.

Palavras-chave (Fonte: tesauro da Unesco): autonomia do aluno; aprendizagem fora da sala de aula; aprendizagem colaborativa; inglês como língua estrangeira; ILE; ouvir. 


\section{Introduction}

\section{Context of the research}

The study described here arose as a result of the low levels of ability and willingness to engage in autonomous learning observed in advanced learner classrooms at a university language center in Ecuador. These observations showed little evidence of any additional practice being undertaken by students other than the work assigned by teachers, and especially that which contributed toward the semester grade.

The lack of autonomy observed in the participants in this research is a symptom of the teaching-learning culture in Ecuador-and indeed, much of Latin America-, which is overwhelmingly teacher-centered and motivated by the desire to achieve certificates issued by teachers, often based on subjective criteria (Edwards, 2019; Yunga-Godoy, Loaiza, Ramón-Jaramillo, \& Puertas, 2016). In an extensive report on the Programme of International Student Assessment (PISA) performance in Latin America, Chaia, Child, Dorn, Frank, Krawitz, and Mourshed (2017) consider a lack of individual growth mind-sets and a poorly developed ability to take responsibility for success in secondary-school students to be key factors limiting progress in PISA scores in the region. Furthermore, language learning continues to be viewed as a largely academic subject dominated by rules and right or wrong answers, mediated by the teacher and institution, rather than the individual user's ability to perform real-world tasks based on the development of competences. These are ingrained behaviors that require a structured and consistent intervention if they are to be transformed. Therefore, the five-week intervention described below was conceived as an indicator of the potential for change in the autonomous learning behavior of students and to explore approaches to achieving a more long-term behavioral transformation.

Student autonomy and collaborative learning have both been labeled products of northern European and North American culture (Sonaiya, 2002; Tabulawa, 2003) due to the emphasis on individualism within a broad social network found in those cultures. There is an 
extensive literature that critiques the imposition of these and other educational paradigms on societies whose view of individual and social relationships is historically distinct, with special emphasis on the conflict between autonomy and African and East Asian cultures. There is no corresponding corpus of research into the situation as experienced in Latin America. However, the authors of this study subscribe to the view that "there are no intrinsic differences that make students in one [cultural] group either less, or more, capable of developing whatever forms of autonomy are seen as appropriate to language learning" (Littlewood, 1999, p. 88). Therefore, there is no ethical question arising from encouraging autonomy in this context: It is an effective approach that enjoys a broad base of support among authors and practitioners aimed at ensuring continued progress for advanced learners and, as an action research project, was undertaken primarily in the best interests of the participants in this study.

\section{Current State of the Debate and Research Aims}

Learner autonomy in Western educational models, and specifically in English as a Foreign Language (EFL) learning, is well established as an essential element of the teaching-learning process. Progress through the intermediate and advanced levels of target language acquisition requires both ability and willingness on the part of students to manage their own learning (Benson \& Cooker, 2013). Of these two behavioral aspects, "ability" was the focus of earlier debate, starting from the 1980 s with Holec's (1981) seminal work, and practical approaches to fostering student procedural knowledge were then developed by Nunan (1988), Benson and Voller (1997), and others. Following this, "willingness," that is, student motivation for undertaking the responsibility of managing their own learning, while always considered a factor, became increasingly central to the success of approaches seeking to develop student autonomy (Dörnyei \& Murphey, 2003; Dörnyei, Ibrahim, \& Muir, 2015; Ushioda, 2011, 2013). The current synthesis of these two concepts, in which this study was conceived, is that the empowerment that comes from ability promotes willingness to engage, while motivation to learn increases the efficacy of applied procedural knowledge. 
Various authors have also attempted to define stages of autonomy, rather than using a simple learner-centered versus teacher-centered analysis. Littlewood (1999) described "reactive" and "proactive" levels of autonomy, which were complemented by Smith's (2003) "weak" and "strong" pedagogies for autonomy. According to Littlewood's definition, "reactively" autonomous students are familiar with-and regularly use-some learner-centered strategies, but maintain a largely teacher-centered mind-set. Reactive autonomy and weak pedagogies are certainly not regarded as undesirable, but there is a consensus that the goal of developmental strategies in this area should be eventually to produce "proactive" behavior through "strong" pedagogies (Benson, 2007). In this definition, learners should, therefore, also show understanding and appreciation of the benefits of being autonomous and actively seek out opportunities for their own development, and this view underpins the first aim of this research:

To assess the extent of the development of "proactive" autonomous behavior in university language center students.

The definition of the context in which autonomous learning should take place has also shifted over recent decades. Initially, authors emphasized the ability of the student to learn effectively when outside of the classroom, in total independence (Knowles, 1975; Holec, 1981). During the 1990s, the importance of autonomy within the classroom became the central focus. This not only included the general transfer of control from teacher to student (Nunan, 1997, 2003), but the development of student-student interdependence as part of the Vygotszkian collaborative and social-learning approach might also be extended outside of the classroom, in what was once the domain of the fully independent, isolated learner (Nunan \& Richards, 2015; Murray, 2015, Reinders \& Benson, 2017). Several authors have put forward the benefits of encouraging collaboration within a learning community (Ke \& Hoadley, 2009; Murdock \& Williams, 2011), among which motivation for practice or study stands out (Dörnyei \& Ushioda, 2011). For autonomy to be successful in this out-of-classroom context, students must have the ability and willingness to learn both independently of the teacher and interdependently with peers (Benson \& Cooker, 2013).

It should be borne in mind that collaborative autonomy outside of the classroom is not simply a natural progression of the approaches 
that originated in lesson contexts. Starting with Little's (2001) concept of tele-collaboration at the beginning of the broadband age, subsequent improvements in information and communication technology (ICT) over the last ten years, and particularly those resulting from the so-called Web 2.0 revolution (Guth \& Helm, 2010), have led to the constant interconnectivity of individuals for the exchange of information, opinion and experiences. This has made the extension of the classroom-based social-learning group a reality that must not only be recognized, but exploited to maximum advantage (Reinders \& White, 2016). A large number of studies have been carried out in the last ten years examining the impact of tele-collaboration on autonomy. Not all have been encouraging (see Carrió-Pastor, 2015), but most have established a positive correlation; the studies by Lys (2013) - about the impact of digital collaboration on oral skills_and Wang (2014)_on the improvement in written communication through wikis-standing out as clear indicators of the potential for out-of-class collaboration through technology. McLoughlin and Lee encapsulated this technological zeitgeist as early as 2010: “...digital-age students want an active learning experience that is social, participatory and supported by rich media... [and also have] a growing appreciation of the need to support and encourage learner control over the whole/entire learning process" (Mcloughlin \& Lee, 2010, p. 28). Butler-Pascoe (2011), following a review of nearly 50 years of computer-assisted language learning (CALL) manifested the increasingly central importance of internet-based collaboration to student autonomy and learner-centeredness as the twenty-first century progresses. More recently, Carrió-Pastor (2018), in an extensive survey of virtual platforms used in language learning, sees these innovations as now essential to maximizing progress in learning both in motivational considerations and in the rate of acquisition. The intervention described in the following sections was undertaken as part of the ongoing development of approaches that seek to foster this complex, but potentially highly effective behavior in EFL students. This was the second aim of the research:

To evaluate the extent of the motivational impact of collaboration on encouraging "proactive" autonomous behavior in university language center students. 


\section{Action Research Design}

As described above, advanced students at the university language center manifested limited learner independence, and since learner needs defined the choice of intervention, the study used an action research approach throughout. Three of the authors were also the class teachers of the participants, and any change in the learning behavior was sought not merely as a question of academic interest but for the immediate and long-term benefit of the participating students (Siegel, 2018). As part of this consideration, a particularly weak area of language competence was chosen, so that the additional intervention would be of maximum benefit to learners in their progress in EFL. At the same time, it was necessary to have a narrow focus in order to make meaningful measurements of changes in behavior. To these ends, listening comprehension was the skill identified as needing extensive and structured intervention, based on the metadata of historical test results at the university language center, and on the individual data gathered by the research team from diagnostic assessments and observations. It is worth noting, at this point, that the research did not seek to measure a quantifiable impact on listening skills-improved listening ability per se was not the direct objective of the intervention-but rather how participants invested time and effort in listening outside of the classroom and exercised judgment in selecting appropriate material for listening practice. Improvement in listening skills may be viewed as a corollary to this investment by students, but it was not necessary to provide evidence of the degree of improvement in order to judge the success of the intervention. Moreover, the quantifiable impact on listening skills resulting from this approach is the subject of the future, second cycle of this action research.

The intervention described below was, therefore, grounded in the hypothesis that providing students with the opportunities to collaborate outside of the classroom in an appropriate development of their listening skills would have a significant motivational impact on the participants and lead to a degree of "proactive" autonomous behavior, rather than the hitherto "reactive" behavior observed.

The design of this intervention was guided by the questions for future research posed by Reinders and White (2016), by Ushioda (2016), 
and by general approaches outlined in Lamy and Magenot (2013), while specifically self-directed listening research design was based partly on a study of students of Spanish by Mideros and Carter (2015). Elements of the mechanics of adapting the Moodle ${ }^{\circledast}$ platform for collaborative learning in EFL were taken from Bateineh and Mayyas (2017), and general guidelines on the use of YouTube ${ }^{\circledR}$ in tandem with various social networking tools to provide a virtual space for collaborative autonomous learning to take place were partly based on the studies by Alwehaibi (2015) and Rennie (2012). Meanwhile, approaches for using the variety of genres available on YouTube were taken from numerous recent studies (see, for example, Lin and Siyanova-Chanturia [2014] for their guidance on using TV dramas and comedies, and Coxhead and Bytheway [2014] for the use of TED ${ }^{\circledR}$ talks). The following section describes the specific considerations for the design of the intervention and the tools for measuring changes in autonomous behavior and collaboration.

\section{METHOD}

\section{Description of the intervention}

The interventions used as basis for this research were carried out at a university language center in Ecuador over a five-week period at the end of the spring semester in 2018. The participants were 154 EFL students divided among three Common European Framework of Reference (CEFR) levels:

- Two fifth-level classes (mid-level B2), comprising 41 participants.

- Three seventh-level classes (B2/C1 borderline level), comprising 59 participants.

- Three eighth-level classes (low C1 level), comprising 54 participants. Moodle ${ }^{\circledR}$ was adapted for sharing student-selected videos targeted at developing listening comprehension of authentic sources, and for providing a forum for comments posted by the participating students on the content, interest level and difficulty of the videos. For these pur- 
poses, each of the three levels in the study was a learning community of between 45 and 60 participants, in which all members of the different classes within each level had access to the videos and forums selected by their peers of the same level.

During each of the five weeks, two volunteers from every one of the participating classes selected a video of their choice from YouTube $^{\circledast}$ or other open-access online site. Each volunteer had complete freedom of choice of topic and genre, provided the video was no more than 10-minutes long, was in English and was suitable for viewing by a teenage audience. The link to the video was posted on a dedicated forum within the Moodle ${ }^{\circledR}$ platform for the corresponding level, together with two questions posed by the volunteer relating to the content of the video. All participants were made aware of new postings and were then free to watch any or all (or none) of the videos pertaining to their level (six videos per week, or four for level 5). Participants could post comments on the forum thread for the video they had watched, which could be related to the content, interest level or difficulty of the video: There were no specific requirements, and the two questions did not need to be answered explicitly in the forum. At the end of each week, the forum was closed and a new one opened ready for the next volunteers' postings. All participants then completed a questionnaire about their activity on the Moodle ${ }^{\circledast}$ forum for that week.

\section{Research instruments and analytical tools}

The study implemented an explanatory mixed-methods design (Creswell, as cited in Mertler, 2014), in which quantitative data and qualitative data were gathered throughout the five-week period. Quantifiable data came from weekly questionnaires completed by the 154 participants after viewing one or more peer-selected videos. These instruments collected feedback in numerical form on student engagement with the videos and forums, using closed-item questions of a variety of types, including Likert scaling and ranking (Ary, Cheser, \& Sorenson, 2010).

Qualitative data came from two sources. Open-ended written feedback was provided voluntarily in the final week of the intervention in the form of individual student reflections on the experience of selecting and viewing videos on Moodle ${ }^{\circledR}$ and using the forums for interaction with 
peers. Secondly, interviews were carried out with two randomly selected students per class, resulting in a total of sixteen interviewees, which provided further open-ended responses. The interviews were semi-structured, giving students the opportunity to express themselves in greater depth on their opinion of various aspects of the intervention and were conducted by the non-participating researcher in order to encourage the volunteering of detailed opinion and to reduce bias (Dowsett, 1986). The reports of the teacher-researchers provided additional qualitative data based on their observations over the course of the intervention and inspection of the collective digital resource created by the 154 participants in the form of forum threads and the banks of selected videos.

To analyze the quantitative data provided by the weekly questionnaires, the study used four parameters to assess the evidence of development of "proactive" autonomous behavior, as set out in Table 1. These parameters were chosen as indicators of the following aspects of autonomy: 1) time invested in skills practice; 2) awareness of the need to have varied practice; 3) ability to judge the usefulness or relevance of material for practice; and 4) ability to judge the difficulty level of material for practice. This is not intended to be an exhaustive list of proactive behaviors, but it serves as an approximation to the choices, awareness and abilities that a fully autonomous leaner should demonstrate. For each parameter, a threshold was established so that results that crossed the threshold might be considered evidence of proactive autonomous behavior. Results falling below the threshold would show insufficient development of autonomy. The analysis provided by this table would, then, establish the extent to which the first research objective had been reached. Qualitative information from written feedback and interviews was used where appropriate to corroborate the analysis of the quantitative data and, thereby, lend greater validity to the results.

Table 1. Parameters for measuring autonomous behavior within the study

\begin{tabular}{|ll|}
\hline $\begin{array}{c}\text { Parameter of autonomous } \\
\text { behavior }\end{array}$ & Threshold of compliance with parameter \\
\hline $\begin{array}{l}\text { 1. Time dedicated to listening } \\
\text { activities outside the } \\
\text { classroom. }\end{array}$ & $\begin{array}{l}\text { Participants view one video at home each } \\
\text { week and each video at least twice. }\end{array}$ \\
\hline
\end{tabular}




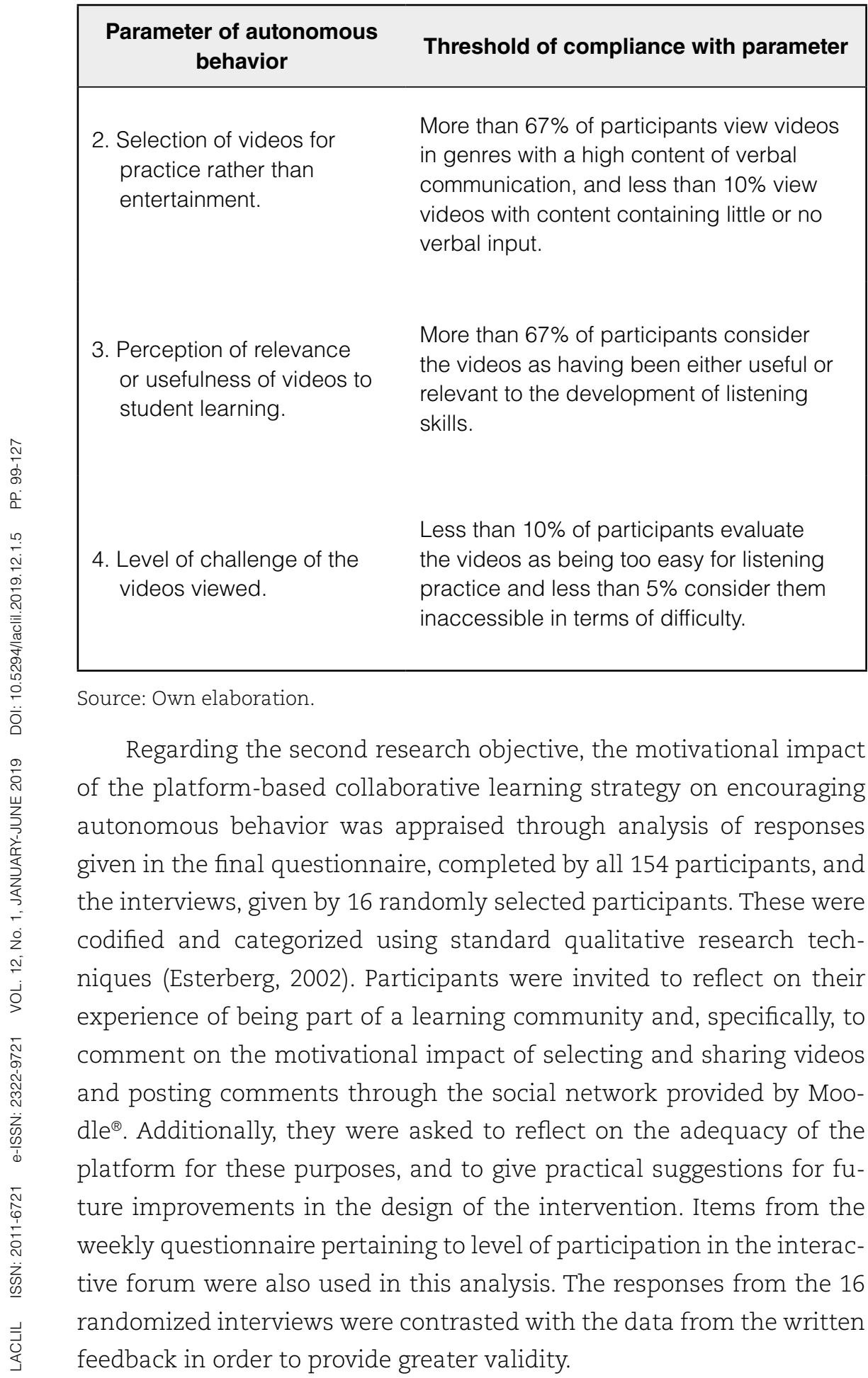




\section{RESULTS}

The intervention lasted five weeks, in which 30 videos were shared by the $7^{\text {th }}$ and $8^{\text {th }}$ level learning communities, 20 videos by the $5^{\text {th }}$ level community, and a total of 797 comments were posted across all levels and classes. Analysis of participation from the weekly questionnaires using the established parameters showed a degree of development of student autonomy classifiable as "proactive" (Littlewood, 1999); therefore, the first objective was met, albeit with deficiencies.

\section{Parameter 1: Number of videos viewed per week}

Table 1 stipulates a threshold of one video viewed on average each week for this parameter. Responses to the weekly questionnaires, corroborated by visual inspection of the Moodle ${ }^{\circledR}$ forum threads, revealed that the collective activity by participants over the five weeks amounted to 754 separate viewings of posted videos, which corresponded to 4.9 viewings for each of the 154 participants. Dividing this number across the five weeks of the intervention, participants averaged 0.98 videos viewed per week. There was some variation within each learning community: In level 5 , the average participant viewed 0.87 videos per week; in level 8, the average was 0.92; in level 7, it was 1.18. There was also variation over the five weeks: Viewing activity showed a peak in week 2 with 1.22 videos viewed per student and a low point in week 5 at 0.67 . Table 1 also stipulates a threshold of 2 viewings per video. Again, analysis of the weekly questionnaires, corroborated by inspection of the forums created by the participants, revealed that videos were viewed 1.97 times before posting a comment. There were, on average, 2 viewings in week 2, and 1.7 viewings in week 5, again showing a slight peak and falling-off in student participation. The distribution of the number of viewings is shown in Figure 1.

According to the research criteria, engagement with the videos was very slightly under the minimum requirement for successful autonomous behavior. However, if an adjustment is made for procedural problems in the final week of the intervention (see discussion), the minimum threshold was exactly equaled by the average participant 
(videos per week $=1$; viewings per video $=2$ ). There was a great variety in individual behavior, ranging from almost no activity (although all participants accessed at least one video over the 5 weeks) to those who viewed several videos, several times each.

Figure 1. Distribution of number of viewings per week

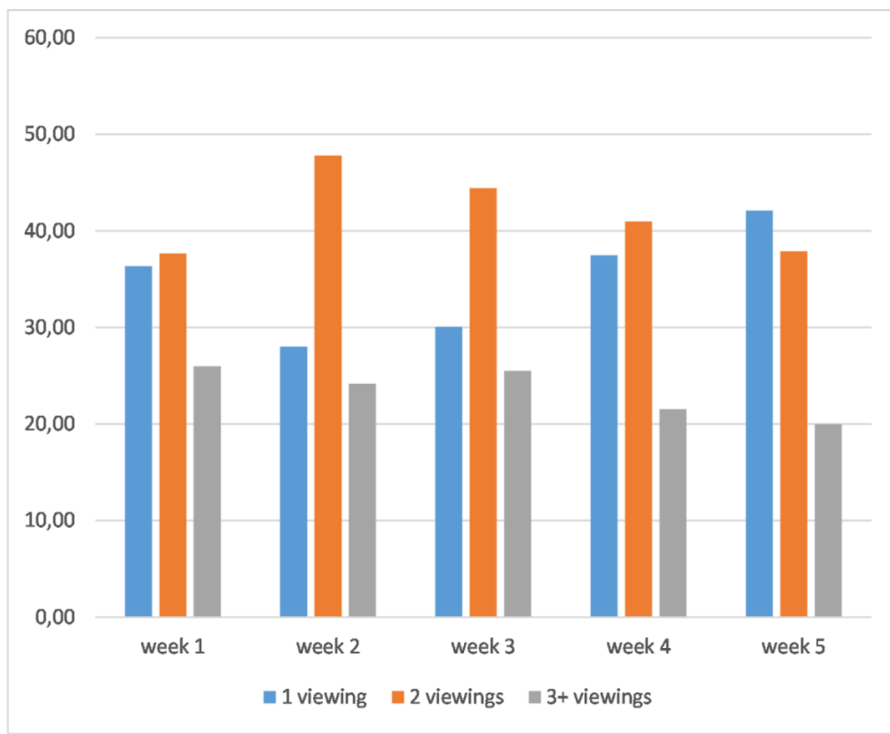

Source: Own elaboration.

\section{Parameter 2: Range of genres viewed}

Table 1 stipulates a threshold of $67 \%$ of students viewing genres of video that have a high content of verbal communication. The genres selected during the intervention that fall into this category were: TED ${ }^{\circledR}$ talks, documentaries, drama, comedy, and talk shows. This parameter also uses a second threshold of less than 10\% viewing genres considered to provide a low level of verbal input. These were videos classified as music and "other" (inspirational or amusing videos of a variable verbal content). The relative proportions of the eight different genres selected during the intervention are shown in Figure 2.

During the intervention, $\mathrm{TED}^{\circledR}$ talks, documentaries and talk shows made up over half of all material watched. Overall, $69.5 \%$ of the viewed videos contained, by definition, a high proportion of verbal communication, which passes the first threshold requirement. Music videos 
made up $5 \%$ of the total on average, which passes the second threshold requirement. However, there was a peak in music video selection of over $10 \%$ in the first two weeks of the intervention. The category of "other" averaged at around a fifth of all viewings but rose steadily from $10 \%$ of selections to over $25 \%$ by week 5 . The content of this category was variable, with some classifiable as mainly visual, while others had a high verbal content.

Figure 2. Proportion of different genres viewed over the intervention

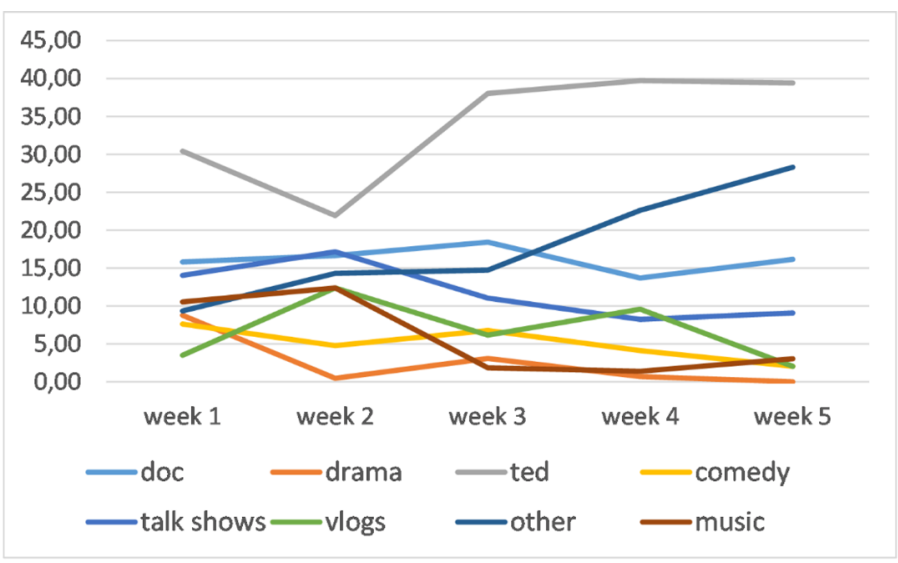

Source: Own elaboration.

These results are consistent with the analysis of written feedback and interview responses, which showed that almost all students recognized that selections should have a high verbal content, and that musical and visual content were suboptimal for listening development. The written feedback of the 154 participants showed that $72 \%$ found the selection of content appropriate for their listening development, while $25 \%$ wished for a greater variety. The majority of those critical of content cited repetition of format or topic either across the weekly selection of videos, or over the course of the intervention. The remaining $3 \%$ called for more music videos, as they felt this was the best way for them to improve their listening. In responses from the 16 randomly selected interviewees, six (38\%) manifested that a large proportion of selections were repetitive or unengaging and that $\mathrm{TED}^{\circledR}$ talks and similar selections should dominate less in the future, while the remaining 10 (62\%) were positive or very positive about the selection of content for viewing. 


\section{Parameter 3: Usefulness or relevance of videos}

Table 1 establishes a threshold of $67 \%$ of participants evaluating the selected videos as useful or relevant for their listening development. Feedback given in the weekly questionnaires used a Likert scale of 1 ("not useful at all") to 5 ("very useful"). In evaluating the fulfillment of this threshold, all ratings of 4 and 5 and exactly half of the ratings of 3 were considered generally positive, while ratings of 1,2 and half of the ratings of 3 were considered generally negative. Table 2 shows the distribution of these ratings from the weekly questionnaires.

Table 2. Numbers and proportions of ratings for usefulness of the video material viewed during the intervention

\begin{tabular}{|c|c|c|c|c|c|}
\hline $\begin{array}{c}\text { Rating } \\
\text { Week }\end{array}$ & $\mathbf{1}$ & $\mathbf{2}$ & $\mathbf{3}$ & $\mathbf{4}$ & $\mathbf{5}$ \\
\hline Week 1 & 4 & 12 & 55 & 51 & 34 \\
\hline Week 2 & 1 & 14 & 63 & 69 & 38 \\
\hline Week 3 & 1 & 4 & 54 & 75 & 19 \\
\hline Week 4 & 5 & 9 & 54 & 58 & 18 \\
\hline Week 5 & 6 & 3 & 32 & 38 & 18 \\
\hline $\begin{array}{c}\text { Percentage } \\
\text { of total }\end{array}$ & 2.3 & 5.7 & 35.1 & 39.6 & 17.3 \\
\hline
\end{tabular}

Source: Own elaboration.

The threshold for parameter 3 was passed, with $74.5 \%$ of students classifying the material as generally useful (adding the ratings of 5 and 4 plus half of the ratings of 3), and $56.9 \%$ gave a very positive evaluation (ratings of 4 and 5). These results come from the written feedback provided in the final questionnaire, in which $80 \%$ of participants found the intervention useful with no reservations or criticisms. A further 10.7\% found the videos useful but with some reservations regarding the material selected for viewing, and 9.3\% found the video material to have been of limited use or relevance to them. Criticism focused on the random nature of the material selected and called for greater alignment with curriculum topics. In other words, a significant minority felt that the listening material should complement classwork, 
rather than function as independent comprehension practice. Isolated comments criticized the lack of engaging material offered, which was considered demotivating.

These criticisms were echoed, but in a slightly greater proportion, in the 16 randomized interviews. Three of the sixteen students (19\%) manifested an overall negative response to the material and three (19\%) gave an overall mixed response, suggesting that more guidance be provided on the selection of the videos, or else greater choice be given, since they had found some of the material repetitive or unengaging. The remaining ten (62\%)-slightly less than the two thirds threshold established for this parameter-were either positive or very positive regarding the usefulness and relevance of the material to their listening development.

\section{Parameter 4: Level of challenge of the material viewed}

The purpose of this parameter was not to measure the participants' listening ability, but rather whether the selected material was appropriate for their listening development. Table 1 establishes a threshold of $10 \%$ or less considering the videos excessively easy in comparison with participant listening ability, together with a threshold of less than $5 \%$ finding the videos so difficult as to render them inaccessible. Figure 3 shows the distribution of participant evaluations within this parameter. The level of challenge of the material was skewed toward the easier end of the evaluation, with a clear correspondence between instances in which either music or "other"' video selections were favored and a high percentage of evaluations in the "very easy"' category. Nonetheless, the ideal "moderate" level of challenge was the mode in three of the weeks, and week 5 was the only week in which a higher-than-expected proportion found the material "inaccessible." Further to this, the average evaluation of level of challenge across the 5 weeks set against the expected values, based on a normal distribution, shows the skewing toward an evaluation of easy (see Figure 4) with the majority of evaluations lying in the moderate to easy categories.

Overall, the thresholds for parameter 4 were not convincingly passed. When averaging the evaluations over the five weeks, 3.6\% of participants found the material inaccessible while $9.4 \%$ found them 
excessively easy. However, this interpretation masks the fact that evaluations for weeks 1, 2, and 5 all reached or crossed the 10\% threshold for being too easy. At the same time, 19\% found the video selections easier than the expected values based on a normal distribution.

Figure 3. Distribution of evaluation of level of challenge

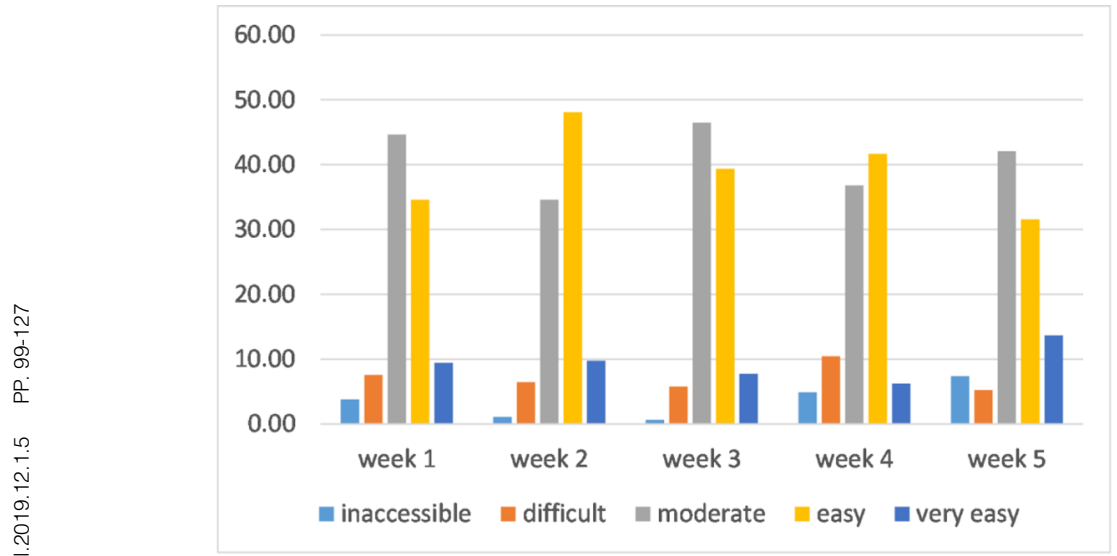

Source: Own elaboration.

Figure 4. Average distribution of level of challenge compared to expected distribution

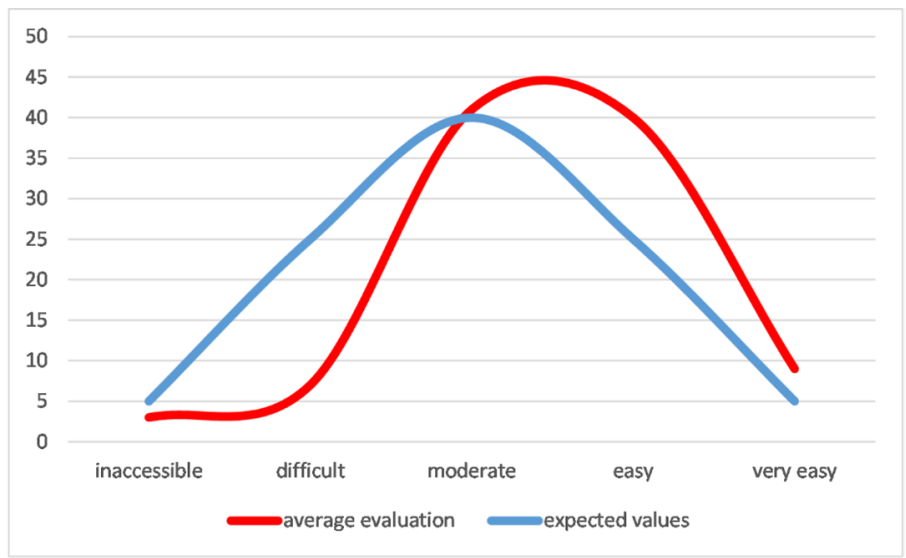

Source: Own elaboration.

In written feedback, the difficulty level was not highlighted as an area for improvement by most participants, indicating that the material was found to be generally adequate in this respect. The few comments that made explicit mention of level of challenge indicated that 
the videos, or the intervention, were generally appropriate for developing listening skills without offering specific details. Due to the paucity of quantifiable data for coded analysis in this respect, Table 3 directly cites all comments that pertain to level of challenge, in which a mixed picture can be seen.

Table 3. Comments given in final feedback on level of challenge

\begin{tabular}{|c|c|}
\hline $\begin{array}{c}\text { Judgment } \\
\text { on level of } \\
\text { challenge }\end{array}$ & \multicolumn{1}{|c|}{ Verbatim comments in written feedback and interview } \\
\hline Very difficult & $\begin{array}{l}\text { "...in most of the videos there weren't subtitles that can help" } \\
\text { "It would be better if the videos have subtitles..." }\end{array}$ \\
\hline $\begin{array}{c}\text { Challenging but } \\
\text { useful }\end{array}$ & $\begin{array}{l}\text { "...some hard to understand, but the complexity was good for } \\
\text { my learning." } \\
\text { "...some very challenging but that was good for learning more." }\end{array}$ \\
\hline Neutral & $\begin{array}{l}\text { "Organize all the videos about language difficulty-easier in the } \\
\text { beginning and it could get harder." }\end{array}$ \\
\hline Very easy & $\begin{array}{l}\text { "Some videos were ok, but it could be more useful if some } \\
\text { students share videos about advanced grammar." } \\
\text { "I think you have to choose better videos, because some } \\
\text { videos were useless." }\end{array}$ \\
\hline
\end{tabular}

Source: Own elaboration.

\section{Student assessment of the collaborative approach to autonomy}

The motivational impact of the collaboration on the development of autonomy, the second research objective, was measured in four ways, based on a coded analysis of written feedback given to all 154 participants at the end of the intervention, and the analysis of the responses given in interview by the 16 randomly selected participants:

\section{General motivation derived from the collaborative design of the intervention}

In randomized interviews, 13 of the 16 participants (81\%) stated that they had engaged in a greater volume and variety of listening material as a result of the video and comment-sharing network than they 
normally do when working individually and in isolation. Eleven (69\%) stated that the collaborative design of the intervention was the most important factor influencing their engagement with the listening material. In written feedback, exactly $50 \%$ of participants explicitly praised the approach of sharing videos and comments as a vehicle to learning.

However, two interviewees (13\%) showed frustration with the narrowness of topics selected by peers, and three (19\%) wished to see teacher-led classwork related to the videos. This perception was echoed in written feedback, in which a significant minority of comments $(16 \%)$ called for a degree of teacher intervention in the future, including some assessment and grading of the listening or class work based on the content of the videos.

The motivational effect on the volunteers who selected videos for sharing

Over the five weeks, 80 of the 154 participants (51\%) had the opportunity to volunteer to select a video to post. Teacher-researchers reported that, during the first two weeks of the intervention, some degree of encouragement had been necessary in order to find enough volunteers. However, later in the process, there were more volunteers than the required two per class. In feedback, only one participant stated that they were opposed to the idea of volunteering. Of the interviews carried out, nine (56\%) were with those who had selected videos for posting. Seven (78\%) of them reported feeling a degree of positive social pressure when making their selections. Their comments indicated that they had been anxious to select a video that would be considered both interesting and useful by the community of their peers. Five (56\%) reported having viewed a wide variety of possible material before making their choice and that they considered aspects of broad appeal of topic, perceived difficulty of comprehension, and variety regarding the selections made in previous weeks before making their selection.

\section{The motivational effect on all participants of interaction on the forums}

The weekly questionnaires revealed that $74 \%$ of the students posted at least one comment per video viewed. However, only $25 \%$ posted more than one comment per video. This self-reporting of the quality of forum 
contributions was corroborated by a review by teachers of participant activity on the weekly forums, which were dominated by isolated comments related directly to the video content, and a developed back-andforth debate between students was less common. In written feedback, $20 \%$ of participants cited the forum as an essential part of the collaborative process, but exactly half of these suggested that greater interaction between students was needed. Meanwhile, in randomized interviews, 6 (38\%) participants cited the forum discussion as a positive aspect of the collaborative process, and 4 (25\%) suggested the forum be improved in order to encourage interaction.

On the other hand, $69 \%$ evaluated their contributions to the forum as having been of at least moderate quality (the guidelines for the weekly questionnaire established that a moderate contribution be at least one full sentence expressing an opinion); $27.5 \%$ made a detailed contribution of several sentences contained in one or more posts; $15.5 \%$ made no comment after watching a video.

\section{The suitability of the Moodle ${ }^{\oplus}$ platform for the purposes of sharing and posting}

The weekly questionnaires provided quantifiable data regarding the accessibility of the process used. At all stages of the intervention, at least $80 \%$ of participants reported feeling comfortable with the platform in general, and their access to the video links and forums in particular. However, the minority who felt very negatively about their use of Moodle ${ }^{\circledR}$ quadrupled from $2.5 \%$, initially, to $8.7 \%$. In written feedback, $5 \%$ of participants indicated that they felt the Moodle ${ }^{\circledR}$ interface had been a barrier to access. However, a further 21\% of participants indicated a degree of frustration at the limitations of the platform. Criticisms focused on the method of posting the videos or comments and on general ease of access to and navigation of the digital platform. In randomized interviews, three participants (19\%) manifested dissatisfaction with Moodle ${ }^{\circledR}$ as the chosen platform, and suggested other media be found or developed for future interventions, the remaining 13 (81\%) were satisfied with the platform for the purpose it was given. 


\section{Discussion}

Following the triangulation of the quantitative data with the analysis of feedback and responses from interviews and observation of forum use, the results obtained from the four parameters may be taken as providing valid indications of participant behavior over the intervention. Analysis showed a significant development in the ability of participants to manage their own learning regarding listening skills practice, while falling short of fully developed proactive autonomy. Three of the aspects of the participants' capacity for autonomous learning -1) time invested in skills practice; 2) awareness of the need to have varied practice; and 3) ability to judge the usefulness or relevance of material for practice-were established in accordance with the four parameters used, while the elements pertaining to the fourth parameter 4) i.e., selecting an appropriate level of challenge) were not satisfactorily established. Parameter 1 was complied with, but by a bare minimum according to the thresholds stipulated. Nonetheless, it is worth noting that participation in the intervention was affected by external circumstances in week 5, which may have led to the drop in both the quantity and quality of viewings and comments.

In consideration of the stages of autonomy, the average participant had moved from the baseline of teacher-dependence toward a measurable behavior characterized by Littlewood as "proactive" or by Smith as "strong" forms of autonomy (Smith, 2003; Littlewood, 1999). However, there is considerable room for further development in the future; for example, participants need to develop a greater awareness of the appropriate level of challenge and to engage with a greater number of videos per week. The decline in activity in week 5 may also be interpreted as a loss of momentum in participant motivation, rather than being the result of external factors, and a longer intervention is needed in order to examine the sustainability of participant engagement in this, or similar, processes.

This analysis refers only to this specific instance of autonomous behavior, that is, how learners approach the development of their own listening comprehension skills. The authors make no claim to having established a broader autonomous mind-set that the participants might apply to any aspect of their learning, although the ability and mo- 
tivation gained during the intervention should be partially transferrable to other skill areas. Indeed, due to the strongly teacher-centered educational culture of Ecuador (Yunga-Godoy, et al., 2016), it is to be expected that far-reaching transformations of autonomous behavior should require more extensive processes than those described here. However, the modest success of this approach to autonomy in listening development might serve as a model for changes to be implemented in other areas of the EFL curriculum in this and other educational contexts.

Those participants whose feedback called for greater teacher involvement in the process remained in the 'reactive' or 'weak' stage of autonomy development (Smith, 2003; Littlewood, 1999). Table 4 contains a selection of suggestions from participants on how teachers should control the learning process. Requiring a grade for work, or suggesting the entire process be carried out in class under teacher supervision clearly shows underdeveloped autonomous behavior. Those comments that suggested there be a follow-up in class to the practice done at home are not incompatible with autonomy, but still show a "reactive" mind-set, since they indicate a need for the teacher to validate what has been done by the learner, or to give tacit acknowledgement of the extra effort made by individuals.

Table 4. Suggestions given in feedback on how to increase teacher control of the learning process

\begin{tabular}{|c|c|}
\hline $\begin{array}{l}\text { Description of } \\
\text { suggestion }\end{array}$ & Verbatim comments in written feedback and interview \\
\hline $\begin{array}{l}\text { Contribution toward } \\
\text { semester grade }\end{array}$ & $\begin{array}{l}\text { "...the comments could be as extra points or help in } \\
\text { something to students. Motivate to student to use the } \\
\text { platform." } \\
\text { "Should be more activities with extra points" }\end{array}$ \\
\hline $\begin{array}{l}\text { Classwork as a } \\
\text { follow-up to video } \\
\text { viewing }\end{array}$ & $\begin{array}{l}\text { "I suggest that the Moodle can be more interactive through } \\
\text { a test, or summers [sic] into class after saw the videos." } \\
\text { "Discuss about the videos in class every Monday" } \\
\text { "I think it might be more useful to discuss them [videos] in } \\
\text { class rather than in the platform..." }\end{array}$ \\
\hline $\begin{array}{l}\text { Greater teacher- } \\
\text { centeredness in } \\
\text { general }\end{array}$ & $\begin{array}{l}\text { "I think that the English organizer have to organize other } \\
\text { activities to get new knowledge" } \\
\text { "I consider it could be better to do this kind of activity in } \\
\text { classes" }\end{array}$ \\
\hline
\end{tabular}

Source: Own elaboration. 
These comments notwithstanding, the majority of participants, both through their active and consistent participation in a fully student-centered intervention, and in the nature of their feedback, demonstrated a degree of ability and willingness to work toward their own skill development, independently of the teacher, and in collaboration with peers.

The collaborative and social dimension provided by the use of the digital platform, both for sharing and commenting, was considered highly motivating and was evaluated as the most important factor influencing engagement with the videos by more than three quarters of the participants. Benson and Cooker's (2013) contention that "learner autonomy is now understood to be a social capacity that develops through 'interdependence' rather than 'independence'" (p. 8) is strongly supported by the findings. Perhaps more convincingly than the objective of developing the ability to behave autonomously, this second objective of establishing the connection between peer collaboration and willingness to be autonomous was reflected in participant feedback.

However, there were areas where the motivational effect of collaboration could have been more strongly evidenced. Participants often used the discussion forum as a vehicle for acknowledging their having viewed a video and their general opinion of it, and it did not lead to a back-and-forth debate. There were three instances of the forums being used to post a follow-up video by participants who had been particularly stimulated by a video selection and felt their peers might be interested in viewing related content. Such a fully integrated forum thread-an initial video selection, posting of comments by peers, debate on the content of the video, and one or more follow-up videos on a similar topic-could provide very significant motivation for engaging with greater video content. A fully interactive forum might follow the social autonomous model described by Lewis (2015), with the addition of video content. In order to achieve this elevated level of interaction and interdependence through forums, future interventions would certainly require more time to consolidate such behavior among learners.

Again, the decline in participation in week 5 may be interpreted as an indicator that the collaborative approach used in this intervention may not be fully sustainable over longer periods of time. If motivation 
were to decrease over time, some teacher involvement may be necessary in order to inject renewed interest among participants, in which case there would be a loss of proactive autonomy. At the institution in which this intervention took place, in Ecuador, and in Latin America in general, the strong teacher-dependent culture is likely to act as a constant brake on this spontaneous development of autonomous behavior. Longer interventions, or longitudinal studies over several semesters may reveal that autonomous ability and the willingness to engage generated by collaboration are not fully self-sustaining. Rather, short periods of highly motivated autonomous learning may result from teacher-led initiatives, and such initiatives may need to be introduced continually, as part of the learning curriculum, in order to maximize the benefits of autonomous skills practice. These are considerations for future analysis, which, together with other recommendations for changes in the design of similar studies and classroom interventions, are discussed below:

- A longer intervention beginning earlier in the semester is required, as was called for in participant feedback. If the decline in participation in week 5 was due to external issues at the end of the semester, this must be adjusted; if there are inherent problems of motivational sustainability, these must be given time to reveal themselves and be analyzed.

- Although the use given to the Moodle ${ }^{\circledR}$ platform in the intervention was not widely criticized, both participants and teacher-researchers suggested making use of technologies that allow constant interconnectivity within the learning community, either as a replacement for or as a complement to Moodle ${ }^{\oplus}$. A generation increasingly based on mobile, rather than desk-top devices (Lyddon, 2016) may respond well to instant messaging applications such as WhatsApp ${ }^{\circledR}$. The correct balance of older, dedicated educational platforms, and the most recent social networking applications could establish the "nexus between digital literacies, autonomy, and the globalization of interpersonal communications," which Benson (2013, p. 841) cites as a key to future development in this area.

- As discussed above, the development of a sustained exchange of interactions in the forums as a response to videos selected and posted, including the selection and posting of additional, related 
videos for further listening practice may prove both motivating and rewarding in terms of skills practice. Again, an improved digital interface may help this process. Recent studies into Flipgrid ${ }^{\circledR}$ (Green \& Green, 2018; Stoszkowski, 2018), an educational application specifically designed for video sharing, have indicated that the ease of access and the possibility of posting verbal, rather than written comments may encourage greater participation.

The next stage of this action research is to quantify the impact of collaborative autonomous skills development on listening ability in absolute terms. A similar intervention (adjusting for the recommendations outlined above) set against a baseline and final measurement of comprehension is proposed.

\section{References}

Alwehaibi, H. (2015). The impact of using YouTube in EFL classroom on enhancing EFL students' content learning. Journal of College Teaching \& Learning, 12(2), 121-126. Retrieved from https://eric.ed.gov $/ ? \mathrm{id}=\mathrm{EJ} 1061416$

Ary, D., Cheser, L., \& Sorensen, C. (2010). Introduction to research in education. Belmont, CA: Wadsworth.

Bateineh, R., \& Mayyas, M. (2017). The utility of blended learning in EFL reading and grammar: A case for Moodle. Teaching with Technology, 17(3), 35-49. Retrieved from https://eric.ed.gov/?id=EJ1149423

Benson, P. (2007). Autonomy in language learning and teaching (Stateof-the-art article). Language Teaching, 40(1), 21-40. DOI: https://doi. org/10.1017/S0261444806003958

Benson, P. (2013). Learner autonomy. TESOL Quarterly, 47, 838-843. DOI: https://doi.org/10.1002/tesq.134

Benson, P., \& Cooker, L. (2013). The applied linguistic individual: Sociocultural approaches to identity, agency and autonomy. Sheffield, UK: Equinox.

Benson, P., \& Voller, P. (1997). Autonomy and independence in language learning. London, UK: Longman.

Butler-Pascoe, M. E. (2011). The history of CALL. International Journal of Computer-Assisted Language Learning and Teaching, 1(1), 16-32. 
Carrió-Pastor, M. L. (2015). Do online collaborative activities foster autonomy on second language reading and writing? Language Teaching Tomorrow, 1, 1-6. Retrieved from http://urn.fi/urn:nbn:fi:jamk-issn-2343-0281-9

Carrió-Pastor, M. L. (2018). Virtual environments for teachers. In M. L. Carrió-Pastor (Ed.), Teaching language and teaching literature in virtual environments (pp. xiii-xxi). Singapore, Republic of Singapore: Springer.

Chaia, A., Child, F., Dorn, E., Frank, M., Krawitz, M., \& Mourshed, M. (2017). What drives student performance in Latin America. Retrieved from http:// mckinsey.com/industries/social-sector/our-insights/what-drives-student-performance-in-latin-america

Coxhead, A., \& Bytheway, J. (2014). You will not blink: Learning vocabulary using online resources. In D. Nunan \& J. Richards (Eds.), Language Learning Beyond the Classroom (pp. 65-74). New York, NY: Routledge.

Dörnyei, Z., Ibrahim, Z., \& Muir, C. (2015). "Directed Motivational Currents": Regulating complex dynamic systems through motivational surges. In Z. Dörnyei, P. D. MacIntyre, \& A. Henry (Eds.), Motivational dynamics in language learning (pp. 95-105). Bristol, UK: Multilingual Matters.

Dörnyei, Z., \& Murphey, T. (2003). Group dynamics in the language classroom. Cambridge, UK: Cambridge University Press.

Dörnyei, Z., \& Ushioda, E. (2011). Teaching and researching motivation (2 ${ }^{\text {nd }}$ Ed.). Harlow, UK: Pearson.

Dowsett, G. (1986). Interaction in the semi-structured interview. In M. Emery (Ed.), Qualitative research (pp. 50-56). Canberra, Australia: Australian Association of Adult Education.

Edwards, R. (2019). Frustration and hope: A review of the response undertaken in national education programmes to lower-than-expected rates of foreign language acquisition. Investigación y Desarollo, 11(1), 5-16. Retrieved from http://revistas.uta.edu.ec/erevista/index.php/ dide/article/view/630

Esterberg, K. (2002). Qualitative methods in social research. Boston, MA: McGraw-Hill.

Green, T., \& Green, J. (2018). Flipgrid: Adding voice and video to online discussion. TechTrends, 62, 128-130. DOI: https://doi.org/10.1007/ s11528-017-0241-x

Guth, S., \& Helm, F. (2010). Telecollaboration 2.0: Language, literacies, and intercultural learning in the 21st Century (Vol. 1). Frankfurt, Germany: Peter Lang. 
Holec, H. (1981). Autonomy in foreign language learning. Oxford, UK: Pergamon.

Ke, F., \& Hoadley, C. (2009). Evaluating online learning communities. Educational Technology Research and Development, 57(4), 487-510. DOI: http:// dx.doi.org/10.1007/s11423-009-9120-2

Knowles, M. (1975). Self-directed learning: A guide for learners and teachers. Englewood Cliffs, NJ: Prentice Hall.

Lamy, M., \& Mangenot, F. (2013). Social media-based language learning: Insights from research and practice. In M. Lamy \& K. Zourou (Eds.), Social networking for language education (pp. 197-213). Basingstoke, UK: Palgrave Macmillan.

Lewis. T. (2015). Learner autonomy and the theory of sociality. In G. Murray (Ed.), Social dimensions of autonomy in language learning (pp. 35-59). London, UK: Pallgrave Macmillan.

Lin, M., \& Siyanova-Chanturia, A. (2014). Internet television for L2 vocabulary learning. In D. Nunan, J. Richards (Eds), Language learning beyond the classroom (pp. 149-158). New York, NY: Routledge.

Little, D. (2001). Learner autonomy and the challenge of tandem language learning via the Internet. In A. Chambers \& G. Davies (Eds.), ICT and Language Learning: a European Perspective (pp. 29-38). Lisse, The Netherlands: Swets \& Zeitlinger.

Littlewood, W. (1999). Defining and developing autonomy in East Asian contexts. Applied Linguistics, 20(1), 71-94. DOI: https://doi.org/10.1093/ applin/20.1.71

Lyddon, P. A. (2016). Mobile-assisted language learning and language learner autonomy. In S. Papadima-Sophocleous, L. Bradley, \& S. Thouësny (Eds), CALL communities and culture-short papers from EUROCALL 2016 (pp. 302-306). DOI: https://doi.org/10.14705/rpnet.2016. eurocall2016.579

Lys, F. (2013). The development of advanced learner oral proficiency using iPads. Language Learning and Technology, 17(3), 94-116. Retrieved from https://pdfs. semanticscholar.org/e291/a9621771507aa5d733c035f4c29036536412. pdf?_ga=2.192698986.1756647733.1568230283-1185055789.1565810546

McLoughlin, C., \& Lee, M. (2010). Personalised and self-regulated learning in the web 2.0 era: International exemplar of innovative pedagogy using social software. Australasian Journal of Educational Technology, 26, 28-43. DOI: https://doi.org/10.14742/ajet.1100 
Mertler, C. (2014). Action research: Teachers as researchers in the classroom (4 $4^{\text {th }}$ Ed). Thousand Oaks, CA: Sage.

Mideros, D., \& Carter, B. (2015). Meeting the autonomy challenge in an advanced Spanish listening class. In G. Murray (Ed.), Social dimensions of autonomy in language learning (pp. 135-154). London, UK: Pallgrave Macmillan

Murdock, J. L., \& Williams, A. M. (2011). Creating an online learning community: Is it possible? Innovative Higher Education, 36(5), 305-315. Retrieved from http://citeseerx.ist.psu.edu/viewdoc/download?doi=10.1.1.475.5829\&rep=rep1\&type=pdf

Murray, G. (2015). Autonomy in language learning as a social construct. In G. Murray (Ed.), Social dimensions of autonomy in language learning (pp. 233-249). London, UK: Pallgrave Macmillan.

Nunan, D. (1988). The learner-centred curriculum: A study in second language teaching. Cambridge, UK: Cambridge University Press.

Nunan, D. (1997). Designing and adapting materials to encourage learner autonomy. In P. Benson \& P. Voller (Eds.), Autonomy and independence in language learning (pp. 192-203). London, UK: Longman.

Nunan D., \& Richards, J. C. (Eds.) (2015) Language Learning Beyond the Classroom. New York, NY: Routledge.

Palfreyman, D. (2003). Introduction: Culture and learner autonomy. In D. Palfreyman \& R. C. Smith (Eds.), Learner autonomy across cultures: Language education perspectives (pp. 1-19). New York, NY: Palgrave.

Reinders, H., \& Benson, P. (2017). Language learning beyond the classroom: A research agenda. Language Teaching, 50(4), 561-578. DOI: http://doi. org/10.1017/S0261444817000192

Reinders, H., \& White, C. (2016). 20 years of autonomy and technology: How far have we come and where to next? Language Learning \& Technology, 20(2), 143-154. Retrieved from https://hdl.handle.net/10652/3552

Rennie, F. (2012). E-learning and social networking handbook. London, UK: Routledge.

Siegel, J. (2018). Researching listening through action research. In J. Liontas (Ed.), The TESOL encyclopedia of English language teaching. Hoboken, NJ: John Wiley \& Sons. DOI: https://doi.org/10.1002/9781118784235.eelt0591

Smith, R. (2003). Pedagogy for autonomy as (becoming-)appropriate methodology. In D. Palfreyman \& R. Smith (Eds.), Learner autonomy across cultures (pp. 129-146). London, UK: Palgrave Macmillan. 
Sonaiya, R. (2002). Autonomous language learning in Africa: A mismatch of cultural assumptions. Language, Culture and Curriculum, 15(2), 106116. DOI: https://doi.org/10.1080/07908310208666637

Stoszkowski, J. R. (2018). Using Flipgrid to develop social learning. Compass: Journal of Learning and Teaching, 11(2), 1-4. DOI: https://doi. org/10.21100/compass.v11i2.786

Tubulawa, R. (2003). International aid agencies, learner-centred pedagogy and political democratisation: A critique. Comparative Education, 39(1), 7-26. DOI: https://doi.org/10.1080/03050060302559

Ushioda, E. (2011). Why autonomy? Insights from motivation theory and research. Innovation in Language Learning and Teaching, 5(2), 221-232. DOI: https://doi.org/10.1080/17501229.2011.577536

Ushioda, E. (2016). Language learning motivation through a small lens: A research agenda. Language Teaching, 49(4), 564-577. DOI: https://doi. org/10.1017/S0261444816000173

Ushioda E. (2013). Motivation and ELT: Looking ahead to the future. In E. Ushioda (Ed.), International perspectives on motivation (pp. 233-239). London, UK: Palgrave Macmillan.

Yunga-Godoy, D., Loaiza, M., Ramón-Jaramillo, N., \& Puertas, L. (2016). Enfoques de la enseñanza en educación universitaria: una exploración desde la perspectiva Latinoamericana. Profesorado: Revista de Currículum y Formación de Profesorado, 20(3), 313-333. Retrieved from https:// recyt.fecyt.es/index.php/profesorado/article/view/54600

Wang, Y.-C. (2014). Using wikis to facilitate interaction and collaboration among EFL learners: A social constructivist approach to language teaching. System, 42, 383-390. DOI: https://doi.org/10.1016/j.system.2014.01.007 